\title{
Earning Rent with Your Talent: Modern-Day Inequality Rests on the Power to Define, Transfer and Institutionalize Talent
}

\author{
Jonathan J.B. Mijs \\ London School of Economics and Political Science
}

\begin{abstract}
In this paper I develop the point that whereas talent is the basis for desert, talent itself is not meritocratically deserved. It is produced by three processes, none of which are meritocratic: (1) talent is unequally distributed by the rigged lottery of birth, (2) talent is defined in ways that favor some traits over others, and (3) the market for talent is manipulated to maximally extract advantages by those who have more of it. To see how, we require a sociological perspective on economic rent. I argue that talent is a major means through which people seek rent in modern-day capitalism. Talent today is what inherited land was to feudal societies; an unchallenged source of symbolic and economic rewards. Whereas God sanctified the aristocracy's wealth, contemporary privilege is legitimated by meritocracy. Drawing on the work of Gary Becker, Pierre Bourdieu and Jerome Karabel, I show how rent-seeking in modern societies has come to rely principally on rent definition and creation. Inequality is produced by the ways in which talent is defined, institutionalization, and sustained by the moral deservingness we attribute to the accomplishments of talents. Consequently, today's inequalities are as striking as ever, yet harder to challenge than ever before.
\end{abstract}

\section{Key words}

Talent; meritocracy; rent; inequality. 


\section{Introduction}

Capital makes the world go 'round. Those who own it reap the rewards. Many of the largest companies in the world are in car manufacturing (Toyota, Volkswagen), petroleum refining (Exxon Mobil, Royal Dutch Shell), and other industries that rely on copious amounts of capital. Social science research describes how ownership of capital is a major source of wealth inequality (Keister and Moller 2000; Killewald, Pfeffer, and Schachner 2017; Piketty 2014). Scholarship points to the unfair advantages capital ownership provides, such as the ability to extract rent beyond its productive value (Atkinson 2015; Sørensen 2000, 1996; Weeden and Grusky 2014). Moreover, capital is passed down intergenerationally to sons and daughters whose only accomplishment is being born to the right set of parents. Some of the wealthiest people in the world today owe their fortune to their family business. From the Waltons (Wal-mart) and Bettencourts (L'Oreal), to the Mars family and the Koch brothers, today's rich belong to the same social groups, networks, and families as those who held the reins generations ago (Chetty et al. 2014; Pfeffer and Killewald 2018).

While scholars, journalists and politicians are scrutinizing the ownership, transmission, and use of capital, much of modern-day inequality has a different guise. Whereas we disapprove of the plutocracy of capital, we celebrate the meritocracy of talent (Littler 2018; Mijs 2019; Mulligan 2018b). The last decades have seen the rise of companies based on little more than great ideas, and a top one percent of athletes, pop stars, managers and executive officers, whose fortunes derive from their unique set of skills and abilities. Today, six out of the ten largest equities in the Standard \& Poor 500 are IT companies built on the creativity, entrepreneurship, and hard work of extraordinary individuals. We speak of talent when an athlete outperforms the competition, when a young politician rises through the ranks of their party, or when two guys in a garage ${ }^{1}$ set up what turns out to be one of the 
largest companies in the world. We laud talent, we love those who have it, and we loathe our own limits; if only we had come up with that idea first, we'd be the Bill, Larry, Sheryl or Oprah with a billion dollars to our name.

There is a shadow side to the meritocracy of talent. In the world of talent, success is driven by good ideas, ambition, and hard work. Inequality simply reflects their uneven distribution: some of us are brighter, aim higher, work harder. It is a compelling story, but one with cruel consequences. When talent is the basis for success, and differences in talent are the source of economic fortune, what right do we have to complain about inequality and its excesses? Looking at society through the lens of talent equates success with merit, failure with incompetence. Talent consecrates people's privileged place in society (Accominotti 2018; Khan 2010). Talent today is what inherited land was to feudal societies; an unchallenged source of symbolic and economic rewards. Whereas God sanctified the aristocracy's wealth, contemporary privilege is legitimated by talent. Consequently, today's inequalities are as striking as ever, yet harder to challenge than ever before.

In this paper, I argue that talent and capital have much more in common than meets the eye. I will show that the economic gains of talent rely on a process of rent-seeking previously reserved for the owners of capital. In what follows, I give a brief history of rent to show how the return on talent relies on three processes, none of which are meritocratic: (1) just like capital, talents are intergenerationally transmitted from parents to children; (2) further, what constitutes talent relies on the definitional power of powerful gatekeepers who decide which traits to reward and which to discard; (3) moreover, talents are structural, not individual traits; their economic returns are institutionalized in privileged positions. In sum, I will show that inequality is produced by the ways in which talent is defined, transmitted, and sustained by the moral deservingness we attribute to the accomplishments of talents. 


\section{A short history of rent}

The word rent, to most people, is a reminder of their monthly commitment to a landlord or landlady; the price that comes with the roof over their head. For others, it is a source of income: property owners extract rent by letting real estate to people or businesses willing to pay more than their upkeep requires. We tend to associate the term real estate with houses, and the agents selling them, but it actually refers to buildings as well as land.

Whereas it is ownership of the former that is especially important in today's urban societies, for most of human history land has been the primary source of income and wealth.

Economic theory describes how, starting with David Ricardo's law of rent. Ricardo (1817) defines rent as the individual benefits accrued by owning land, over and above its productive quality. Land, if used for agricultural purposes, for instance, has a productive quality. Ownership of the land however has its own benefit: the ability to extract additional returns in the form of rent. Such benefits derive from artificial limits to the supply of an asset, like in a monopoly (see Marshall 1895). Given a fixed supply of land, the owners can extract returns that greatly exceed its value in a competitive market.

Whereas Ricardo's law of rent continues to inform economic thought, the industrial revolution and the coming of post-industrial society (Bell 1973) meant the concept of rent required an update. Jacob Mincer (1958), Theodore Schultz (1960), and, most notably, Gary Becker (1962) provide the foundation for that by taking the concept of capital to the labor market and to the realm of education. Human capital theory states that our minds and bodies are potential sources of rent as well. To Becker, human capital is how most modern citizens make a living; the market rewards people's investments in productive skills, knowledge, habits and traits: 
"Schooling, a computer training course, expenditures of medical care, and lectures on the virtues of punctuality and honesty [are] capital. That is because they raise earnings, improve health, or add to a person's good habits over much of his lifetime. Therefore, economists regard expenditures on education, training, medical care, and so on as investments in human capital. They are called human capital because people cannot be separated from their knowledge, skills, health, or values in the way they can be separated from their financial and physical assets." (Becker 2002)

Whereas the focus of human capital theory is on the productive quality of education and health, minds and bodies can also be a source of rent. For one, the supply of human capital is artificially limited. As Becker and others have acknowledged, people are not equally positioned to reap the rewards of investments in human capital. Potential investments in human capital are limited by financial constraints, which are a function of the cost of schooling (and the cost of health, among other productive qualities) and opportunities to invest; i.e. the availability of and access to pre-schools, private tutoring and extra-curricular activities, elite colleges, etc. Simply put, you can’t accumulate human capital if you cannot afford school or get in.

The human capital equation however is missing a crucial variable, to which I now turn. Rent-seeking in the age of human capital rests on talent.

\section{Returns $=$ investment $*$ talent}

No amount of schooling will turn a half-wit into a genius. Equally, Einstein may have written his theory of relativity even if he hadn't graduated from high school (which, some sources suggest, he barely did). ${ }^{2}$ In other words, some talent is required for schooling to make 
an impact. In fact, there are good reasons to suspect that a higher level of available talent is likely to produce greater returns on the invested education.

To start, schools are set up to cater specifically to students' talents, either by adjusting the level and pace of learning to students' abilities or by differentiating instruction altogether by sorting students into general and honor's classes, vocational and academic tracks, and other forms of grouping based on ability (Domina, Penner, and Penner 2017; Mijs 2011; Van de Werfhorst and Mijs 2010). Moreover, a student's talents determine whether particular educational opportunities are or aren't available. For instance, remedial classes are offered only to students with learning difficulties, while a great deal of talent is required for a person to be given the opportunity of receiving an Ivy League education as elite institutions purposefully keep enrollment low (more on this point below).

In short, real returns on education equal investment times talent. Minds and bodies become a source of rent when ideas and skills are deemed unique talents which merit a reward beyond their productive qualities. In what follows, I show that there is nothing necessary or natural about talent's economic returns. Just like other forms of capital, talents (1) are intergenerationally transferred; (2) rely on being so defined by powerful gatekeepers; and (3) are institutionalized in positions of privilege and protected professions.

\section{We receive our talents from our parents}

Reflective of the classical Greek meaning of the word $\tau \alpha \dot{\lambda} \alpha \alpha \nu \tau o v$ (money), we receive our talents from our parents. Academic ability, IQ, health, height, and physical attractiveness are just a few of the many traits unequally distributed by the rigged lottery of birth (Fischer et al. 1996; Rimfeld et al. 2018). On top of the genetic gains of birth are a set of social skillsor "cultural capital" to use Bourdieu's (1984) term. Children acquire from their parents and from their social milieu more generally, traits and manners, a sense of entitlement or 
constraint, and a level of (dis)comfort with adults and authorities, which makes school a much more productive space for some than for others. Upper (middle) class parents tend to instill in their children the cultural capital to set them up well for tests and exams (Bourdieu 1984; Yamamoto and Brinton 2010), dream big and aim high (Jackson 2013; Lareau 2011), and assure that teachers give them the attention they demand (Calarco 2011, 2018).

In Bourdieu's words, by failing to take into account the investments already made within the family,

[Human capital theorists] let slip the best hidden and socially most determinant educational investment, namely, the domestic transmission of cultural capital. Their studies of the relationship between academic ability and academic investment show that they are unaware that ability or talent is itself the product of an investment of time and cultural capital. (Bourdieu 1986:244-45)

In other words, talent is inherited, in the strict sense, to the extent that our intellectual ability, health, and other productive traits are based on the genetic makeup we receive from our parents. In a broader sense as well, children's talents depend on their parents (Smeeding, Erikson, and Jäntti 2011). Children rarely make investment decisions themselves; the amount of time, attention and resources parents commit to education ("shadow education") greatly impacts their children's human capital accumulation (Buchmann, Condron, and Roscigno 2010). Taken together, there are vast and consequential differences in people's opportunity to benefit from human capital and extract rent, because of the unequal distribution of talent and early investments therein. Talents, in short are far from the individual quality we make them to be; talent, like capital, is transferred, sustained and cultivated across generations. 


\section{Talent is whatever is so defined}

When Ivy League colleges invented American Football around 1880, a new set of talents was created with it. Some such talents travel better than others; being a good football (soccer) player may earn you respect and, if you're good enough, a living, in as many as 200 countries with professional football leagues. Being good in American Football, by contrast, means much more in one country than anywhere else.

The portability of talent points to a crucial quality: talent's meaning and payoff is context-specific, varying across place and over time. ${ }^{3}$ What is true for American Football is true for musical craft and artistic talent; and even for the traits that people value in others. As I have argued elsewhere (Mijs 2016:20), what constitutes merit is historically contingent and institutionally-specific:

Manliness, aggression, asceticism and (bi)sexuality, for instance, were considered important traits for men to have in Sparta, 400 B.C., and display of such traits was rewarded with social status (De Botton 2005). In Western Europe anno 479, in contrast, pacifism, vegetarianism and asexuality were considered meritocratic traits (ibid.). Similarly changes in meritocratic traits over time are described with regard to the rise of court society (Elias 1939), in the evaluation of American social science and humanities scholarship (Tsay et al. 2003), as well as between men and women today (Prentice and Carranza 2002).

What is termed, considered and concomitantly rewarded as productive traits, skills and knowledge depends on how such are defined by society's gatekeepers. So does the opportunity to earn rent with your talent.

A powerful empirical illustration of this insight comes from Karabel's (2005) archival 
research at Harvard, Princeton and Yale. Digging through their archives, he uncovered detailed minutes and reports describing how in the post-World War II era these elite institutions discussed and devised strategies for keeping out unwanted groups of students, while keeping their gates open to the students they wanted to have. How? By defining merit in ways that their preferred students could meet, but others couldn't. First they included 'character' in the admission criteria as a way to exclude Catholics, then they introduced additional requirements in the form of recommendation letters and personal interviews as a means to weed out the uninitiated. As a means of last resort, they incorporated athleticism into their definition of merit to raise the barrier for purportedly physically-unfit Jewish students.

The take-away from Karabel's study is that definitions of talent are never neutral; how we define qualities like talent, character and merit always benefits some groups of people, while putting others at a disadvantage. Consequently, an important basis of rentseeking lies with those who are in a position to define talent. The definition of talent does not stop at the frontgate; schools continuously draw boundaries between groups of students (e.g. "vocational," "academic," "gifted," "at-risk") (Golann 2015). For those fortunate to fit the mold, these boundaries can produce powerful credentials (degrees) and distinctions (e.g. "magna cum laude"). In the worst-case-scenario, they lead to a student's expulsion, the longterm consequences of which have been described as a "school-to-prison pipeline" (Kim, Losen, and Hewitt 2010; Mittleman 2018; Welch and Payne 2018).

This definitional power extends far beyond the realm of education, into the world of literature (Franssen and Kuipers 2013), fashion (Mears 2010), business (Khurana 2002), and as we will see below, sports. 


\section{Talents are institutionalized in positions of privilege}

Some definitions of talent fluctuate; others are more stable. The main process by which definitions are made to stick is through institutionalization: the rent-producing quality of talent is incorporated in positions that generate rent. Simply put, in order to turn your labor power into money, you need a job or a market for your services. Without either, your hard work and talent will go unrewarded.

Sports offer a good illustration of this process. The ability to jump high, dribble and throw a bouncing ball was institutionalized in the sport of basketball in 1891. Before that time, playing basketball was just that: play. With the institutionalization of the sport, that ability became a skill, and with the establishment of the National Basketball Association in 1946 that skill became a productive quality. As the sport's popularity grew, its valuation rose. Today, a professional basketball player in America can make as much as \$45 million in a season, not taking into account the lucrative sponsorship deals that supplement athletes' salaries.

That dollar figure is the result of a very long process of rent-creation. In fact, that process is still ongoing. Every number of years, players and teams come together to negotiate just how much their talents are worth. Players today make a lot more than what they made a few decades ago, and players in the US make a multitude of what players in other countries make. The difference is the level of institutionalization of the sport and the rent creation that came with it. Rent, in sports, is the difference between an athlete with and one without a job. Whereas the difference in skills, effort and talent may be minimal, the difference in reward is likely to be enormous. Owing to "superstar" markets (Rosen 1981), a very small group of athletes (Lewis and Yoon 2018), college graduates (Clotfelter 2017), fashion models (Mears 2011), and rock stars (Krueger 2005) takes home a disproportional part of the pie. As Mulligan (2018a:178) puts it, superstar earnings "drive a wedge between contribution and 
desert."

In more mundane spheres of life as well, people benefit from institutionalized positions of privilege. Certain professions for instance are protected by what Freidson (1970, 2001) calls 'labor market sheltering': strategies for limiting entry into certain professional groups, such as bar exams for lawyers and board exams for doctors. Such practices allow for professional groups to extract advantages beyond the market value of their human capital. Besides deciding who gains entry into these professions, through such entry requirements, occupational societies set limits to the number of people allowed into their profession, thereby putting a cap on the supply-side of the equation that sets their wages.

Another way occupational groups establish rent-seeking is by institutionalizing demand for their services through government licensing and other forms of occupational closure (Sørensen 1996). When you go to court, you would do well to get an attorney. In fact, in most countries, you will be provided with one, if needed, on the government's dime. Less obvious is the need, institutionalized in many countries around the world, for a (notary) lawyer when purchasing a house, accepting an inheritance, merging two businesses, translating a government document, or transferring an Internet domain. All these monopolistic services derive from government regulation successfully fought for by occupational groups and societies (see Abbott 1988).

Yet another source of rent-seeking is in hiring and pay-setting institutions that do not operate on market principles. CEO wages are set by a board of directors who have an interest in appeasing the person whose salary they control (Bebchuk and Fried 2009; Weeden and Grusky 2014). When a board of directors hires a CEO, they may in earnest be picking the most meritorious candidate. They are unlikely however to have a lot to choose from. The pool of candidates is limited by a long list of structural forces that keep people from rising through the corporate ranks (Khurana 2002). The CEO market, in other words, is a closed 
market:

Closure generates an artificial scarcity of candidates who are considered for the CEO job. The function of closure is not only to limit the competitive field in this way but also to set the terms of competition and to assign the rewards for work done in accordance with these limits. It creates the rules of the game, constituting the boundaries by which people will be judged and criticized. At its core, then, the external CEO labor "market" operates as a circulation of elites within a single, sealedoff system relying on socially legitimated criteria that - contrary to conventional economic wisdom - are not to be confused with relevant skills for the CEO position. (Khurana 2002:205)

In sum, many of the accomplishments celebrated as individual feats in fact reflect the privileged positions people occupy. Such positions depend on a long process of institutionalization through which occupational groups such as lawyers, doctors and basketball players, have established rent-seeking privileges. In short, it's not people and their talents, but talents and their people.

\section{Conclusion}

A growing elite in modern societies has made its wealth not based on their birthright, inherited fortune, or by manifest market manipulations. Today's elite is a meritocracy of great ideas and entrepreneurship, and the special talents of artists, athletes and managerial miracle workers. Or so the story goes.

In this paper I have argued that talent in fact relies on structural advantages that have 
nothing to do with the market nor with merit. The accomplishments of talent rely first on the intergenerational transmission of genetic and cultural endowments from parents to their children. Parents, moreover, provide the cultural competence and economic resources to cultivate their children's productive traits - or lack the means to. In short, both the distribution of and investment in talent depend on the lottery of birth.

The returns on talents further depend on which talents are recognized and rewarded. As illustrated by the history of sports, an American Football player before 1880 was just a guy running around with an egg-shaped ball and a harness on. Today, he can make millions of dollars, given that he's privileged to be playing for an NFL team. Talents, in other words, are institutionally-specific and historically contingent. Much power resides with the persons and institutions that guard the gates of talent.

The opportunity to earn rent from your talent rests on institutional forces. For a person to make an income based on their work, they need a job or market to work. Certain types of work have a payoff that far exceeds their market-value. The talents of lawyers, managers, athletes and artists, have been institutionalized in their respective vocations by processes of social closure. Closure artificially limits entry into professions and occupations, increases demand for services, and manipulates their pay to maximize the return on talent. In short, it may be more accurate to speak of talents and their people, than of people and their talents.

Whereas a further exploration of the topic falls beyond the scope of this paper, it merits mentioning that the undeserved advantages of inheritance, rent-definition, and rentcreation, discussed in this paper, seamlessly coexist with capitalism—-best illustrated perhaps by the countless examples of such instances in contemporary America. The neoliberal emphasis on market, competition and responsibility has helped elevate talent to what is arguably society's most celebrated trait (Hall and Lamont 2013; Littler 2018). 'Investing' in talent and preventing its 'waste' has become a major policy focus in advanced capitalist 
societies (OECD 2008; and see Mijs 2016:16-17), and deemed the best hope for international development (World Bank 2010). Paradoxically, then, pro-market ideology has come to support and celebrate an enemy of the market, economic rent, under the thin veil of talent.

In conclusion, when we buy and sell the myth that today's billionaires started with nothing but a garage and a great idea, we miss the moral means for scrutinizing inequality. Looking at wealth and status as the accomplishments of individual talent, removes the ground for public debate and political action. Talent cannot be faulted, nor can it be taxed. Recognizing the socially-constructed nature of talent and its institutionalized power, is the first and necessary step for an interrogation of the economic and symbolic returns on talents in contemporary society.

\section{References}

Abbott, Andrew. 1988. The System of Professions: An Essay on the Division of Expert Labor. Chicago, IL: University of Chicago Press.

Accominotti, Fabien. 2018. "Consecration as a Population-Level Phenomenon.” American Behavioral Scientist forthcoming.

Atkinson, Anthony B. 2015. Inequality. What Can Be Done? Cambridge, MA: Harvard University Press.

Bebchuk, Lucian A. and Jesse M. Fried. 2009. Pay Without Performance: The Unfulfilled Promise of Executive Compensation. Cambridge, MA: Harvard University Press.

Becker, Gary S. 1962. "Investment in Human Capital: A Theoretical Analysis.” The Journal of Political Economy 70:9-49.

Becker, Gary S. 2002. "Human Capital.” in The Concise Encyclopedia of Economics, edited by D. R. Henderson. Indianapolis, IN: Liberty Fund. 
Bell, Daniel. 1973. The Coming of Post-Industrial Society: A Venture in Social Forecasting. New York: Basic Books.

Bourdieu, Pierre. 1984. Distinction: A Social Critique of the Judgement of Taste. Cambridge, MA: Harvard University Press.

Bourdieu, Pierre. 1986. "The Forms of Capital.” Pp. 241-58 in Handbook of Theory and Research for the Sociology of Education, edited by J. F. Richardson. New York: Greenwood Press.

Buchmann, Claudia, Dennis J. Condron, and Vincent J. Roscigno. 2010. "Shadow Education, American Style: Test Preparation, the SAT and College Enrollment.” Social Forces 89(2):435-61.

Calarco, Jessica McCrory. 2011. “'I Need Help!' Social Class and Children’s Help-Seeking in Elementary School.” American Sociological Review 76(6):862-82.

Calarco, Jessica McCrory. 2018. Negotiating Opportunities: How the Middle Class Secures Advantages in School. New York: Oxford University Press.

Chetty, Raj, Nathaniel Hendren, Patrick Kline, Emmanuel Saez, and Nicholas Turner. 2014. "Is the United States Still a Land of Opportunity? Recent Trends in Intergenerational Mobility.” American Economic Review 104(5):141-47.

Clotfelter, Charles T. 2017. Unequal Colleges in the Age of Disparity. Cambridge, MA: Harvard University Press.

De Botton, Alain. 2005. Status Anxiety. New York: Vintage.

Domina, Thurston, Andrew Penner, and Emily Penner. 2017. "Categorical Inequality: Schools As Sorting Machines.” Annual Review of Sociology 43(1):311-30.

Elias, Norbert. 1939. The Civilizing Process: The History of Manners. Oxford: Blackwell Publishing. 
Fischer, Claude S., Michael Hout, Martin Sanchez Jankowski, Samuel R. Lucas, Ann Swidler, and Kim Voss. 1996. Inequality by Design: Cracking the Bell Curve Myth. Princeton, NJ: Princeton University Press.

Franssen, Thomas and Giselinde Kuipers. 2013. "Coping with Uncertainty, Abundance and Strife: Decision-Making Processes of Dutch Acquisition Editors in the Global Market for Translations.” Poetics 41(1):48-74.

Freidson, Eliot. 1970. Profession of Medicine: A Study of the Sociology of Applied Knowledge. Chicago, IL: University of Chicago Press.

Freidson, Eliot. 2001. Professionalism, the Third Logic: On the Practice of Knowledge. Chicago, IL: University of Chicago Press.

Golann, Joanne W. 2015. “The Paradox of Success at a No-Excuses School.” Sociology of Education 88(2):103-19.

Hall, Peter and Michèle Lamont. 2013. Social Resilience In The Neoliberal Era. Cambridge: Cambridge University Press.

Jackson, Michelle. 2013. Determined to Succeed?: Performance versus Choice in Educational Attainment. Palo Alto, CA: Stanford University Press.

Karabel, Jerome. 2005. The Chosen: The Hidden History of Admission and Exclusion at Harvard, Yale, and Princeton. Boston, MA: Houghton Mifflin Harcourt.

Keister, Lisa A. and Stephanie Moller. 2000. "Wealth Inequality in the United States." Annual Review of Sociology 26(1):63-81.

Khan, Shamus Rahman. 2010. Privilege: The Making of an Adolescent Elite at St. Paul's School. Princeton, NJ: Princeton University Press.

Khurana, Rakesh. 2002. Searching for a Corporate Savior: The Irrational Quest for Charismatic CEOs. Princeton, NJ: Princeton University Press. 
Killewald, Alexandra, Fabian T. Pfeffer, and Jared N. Schachner. 2017. "Wealth Inequality and Accumulation.” Annual Review of Sociology 43:379-404.

Kim, Catherine Y., Daniel J. Losen, and Damon T. Hewitt. 2010. The School-to-Prison Pipeline: Structuring Legal Reform. New York: New York University Press.

Krueger, Alan B. 2005. "The Economics of Real Superstars: The Market for Rock Concerts in the Material World.” Journal of Labor Economics 23(1):1-30.

Lamont, Michele and Annette Lareau. 1988. "Cultural Capital: Allusions, Gaps and Glissandos in Recent Theoretical Developments." Sociological Theory 6(2):153-68. Lareau, Annette. 2011. Unequal Childhoods: Class, Race, and Family Life, Second Edition with an Update a Decade Later. Berkeley, CA: University of California Press.

Lewis, Michael and Yeujun Yoon. 2018. “An Empirical Examination of the Development and Impact of Star Power in Major League Baseball.” Journal of Sports Economics 19(2):155-87.

Littler, Jo. 2018. Against Meritocracy: Culture, Power and Myths of Mobility. Routledge.

Marshall, Alfred. 1895. Principles of Economics. London: Macmillan.

Mears, Ashley. 2010. "Size Zero High-End Ethnic: Cultural Production and the Reproduction of Culture in Fashion Modeling." Poetics 38(1):21-46.

Mears, ashley. 2011. Pricing Beauty: The Making of a Fashion Model. Berkeley, CA: University of California Press.

Mijs, Jonathan J. B. 2011. "Van Terecht Onrecht Naar Pluriform Talent.” Beleid En Maatschappij 38(3):327-33.

Mijs, Jonathan J. B. 2016. "The Unfulfillable Promise of Meritocracy: Three Lessons and Their Implications for Justice in Education.” Social Justice Research 29(1):14-34. Mijs, Jonathan J. B. 2019. “The Paradox of Inequality: Income Inequality and Belief in Meritocracy Go Hand in Hand." Socio-Economic Review forthcoming. 
Mincer, Jacob. 1958. "Investment in Human Capital and Personal Income Distribution." Journal of Political Economy 66:281-302.

Mittleman, Joel. 2018. "A Downward Spiral? Childhood Suspension and the Path to Juvenile Arrest." Sociology of Education 91(3):183-204.

Mulligan, Thomas. 2018a. "Do People Deserve Their Economic Rents?” Erasmus Journal for Philosophy and Economics 11(2):163-90.

Mulligan, Thomas. 2018b. Justice and the Meritocratic State. New York: Routledge.

OECD. 2008. The Global Competition for Talent. Mobility of the Highly Skilled. Paris: Organisation for Economic Co-Operation and Development.

Pfeffer, Fabian T. and Alexandra Killewald. 2018. "Generations of Advantage. Multigenerational Correlations in Family Wealth.” Social Forces 96(4):1411-42.

Piketty, Thomas. 2014. Capital in the Twenty-First Century. Cambridge, MA: Harvard University Press.

Prentice, Deborah A. and Erica Carranza. 2002. "What Women and Men Should Be, Shouldn't Be, Are Allowed to Be, and Don't Have to Be: The Contents of Prescriptive Gender Stereotypes.” Psychology of Women Quarterly 26(4):269-81.

Ricardo, David. 1817. On the Principles of Political Economy, and Taxation. London: J. Murray.

Rimfeld, Kaili, Eva Krapohl, Maciej Trzaskowski, Jonathan R. I. Coleman, Saskia Selzam, Philip S. Dale, Tonu Esko, Andres Metspalu, and Robert Plomin. 2018. “Genetic Influence on Social Outcomes during and after the Soviet Era in Estonia." Nature Human Behaviour 2(4):269.

Rosen, Sherwin. 1981. "The Economics of Superstars.” The American Economic Review 71(5):845-58. 
Schultz, Theodore W. 1960. "Capital Formation by Education.” Journal of Political Economy 68(6):571-83.

Smeeding, Timothy, Robert Erikson, and Markus Jäntti, eds. 2011. Persistence, Privilege, and Parenting. The Comparative Study of Intergenerational Mobility. New York: Russell Sage Foundation.

Sørensen, Aage B. 1996. "The Structural Basis of Social Inequality.” American Journal of Sociology 101(5):1333-65.

Sørensen, Aage B. 2000. "Toward a Sounder Basis for Class Analysis.” American Journal of Sociology 105(6):1523-1558.

Tsay, Angela, Michèle Lamont, Andrew Abbott, and Joshua Guetzkow. 2003. "From Character to Intellect: Changing Conceptions of Merit in the Social Sciences and Humanities, 1951-1971.” Poetics 31(1):23-49.

Van de Werfhorst, Herman G. and Jonathan J. B. Mijs. 2010. “Achievement Inequality and the Institutional Structure of Educational Systems: A Comparative Perspective.” Annual Review of Sociology 36:407-428.

Weeden, Kim A. and David B. Grusky. 2014. "Inequality and Market Failure.” American Behavioral Scientist 58(3):473-91.

Welch, Kelly and Allison Ann Payne. 2018. "Latino/a Student Threat and School Disciplinary Policies and Practices.” Sociology of Education 91(2):91-110.

World Bank. 2010. Talent Abroad Promoting Growth and Institutional Development at Home: Skilled Diaspora as Part of the Country. Washington, D.C.: World Bank. Yamamoto, Yoko and Mary C. Brinton. 2010. "Cultural Capital in East Asian Educational Systems The Case of Japan.” Sociology of Education 83(1):67-83. 


\section{Notes}

1 "We started our company out of our garage," serves to convey the notion that all a successful enterprise needs is a good idea and a lot of hard work. It has become such a common phrase that it is now referred to as the garage trope. It features as the origin myth of Amazon, Google, Apple, Microsoft and Hewlett-Packard, among other companies (https://www.inc.com/drew-hendricks/6-25-billion-companies-that-started-in-a-garage.html).

${ }^{2}$ Einstein did not master French, which was a required topic in his Swiss high school. This is also the most probable reason he failed to gain admission to the prestigious Federal Technical Institute in Zurich. Biographers however note that Einstein showed early signs of his brilliance in high school, and point also to the role of his home environment where "manipulations of electricity and magnetism were a daily preoccupation helped set him on a road that led to his first relativity theory" (https://www.nytimes.com/1984/02/14/science/einstein-revealed-as-brilliant-in-youth.html).

\footnotetext{
${ }^{3}$ Another way to express this quality of talent is to think of it, in Bourdieusian terms, as fieldspecific capital; i.e. the qualities and traits that pay off in a particular (structural) setting (Lamont and Lareau 1988).
} 